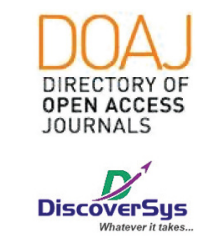

Published by DiscoverSys

\title{
Faktor-faktor yang berhubungan dengan terjadinya hipertensi intraabdominal pada pasien dengan peritonitis di RSUP Sanglah Denpasar dari bulan Januari 2017 - Desember 2018
}

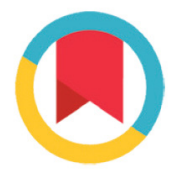

CrossMark

\author{
Krishna Kurnia Pratama ${ }^{1 *}$, Ketut Sudiasa ${ }^{2}$, Nyoman Golden ${ }^{3}$
}

\begin{abstract}
Background and aim: Peritonitis is an emergency condition in the field of surgery due to its several complications. The most challenging is intraabdominal hypertension which can develop into abdominal compartment syndrome. There are several factors that cause intraabdominal hypertension in patients with peritonitis. This study aims to found factors that are associated with the occurrence of intraabdominal hypertension in peritonitis patients at Sanglah General Hospital in January 2017-December 2018.

Method: This research used cross sectional analitic with total sampling technique with 136 peritonitis patients in Sanglah Hospital from Januari 2017 until December 2018 as respondents. Data source obtained from medical report. Bivariat analysis done to find factors related with intraabdominal hypertension in peritonitis patients with chi square method and multivariate analysis with logistic regression.
\end{abstract}

Result: The majority of respondents are male, aged 15-64 years, organs involved in peritonitis in the form of solid organs, peritonitis that occurs through trauma mechanisms, experiencing sepsis, leukocytosis, and not hypoalbumin. Three variables were found to be significantly related they are, peritonitis caused by hollow organ perforation, sepsis condition, and hypoalbumin conditions. Only the sepsis condition has significant relationship with the occurrence of intraabdominal hypertension. Sepsis is 0.262 times more likely to cause intraabdominal hypertension in patients with peritonitis compared to patients without sepsis.

Suggestion: Closely monitoring intraabdominal pressure should be carried out, especially in patients with sepsis, hypoalbumin, and those suspected of having perforations in hollow organs and further research is needed with a larger number of samples and more superior research methods.
1PPDS-1 IImu Bedah, Fakultas Kedokteran Universitas UdayanaRSUP Sanglah Denpasar, BaliIndonesia

${ }^{2}$ Divisi Bedah Trauma, Departemen/KSM IImu Bedah, Fakultas Kedokteran Universitas Udayana-RSUP Sanglah Denpasar, Bali-Indonesia

${ }^{3}$ Departemen/KSM Bedah Saraf, Fakultas Kedokteran Universitas Udayana-RSUP Sanglah Denpasar, Bali-Indonesia

*Korespondensi:

Krishna Kurnia Pratama; PPDS-1 IImu Bedah, Fakultas Kedokteran Universitas UdayanaRSUP Sanglah Denpasar, BaliIndonesia;

kpratama26@gmail.com

Diterima: 03-03-2020

Disetujui: 09-07-2020

Diterbitkan: 01-08-2020
Keywords: intraabdominal hypertension, hypoalbumin, peritonitis, sepsis

Cite This Article: Pratama, K.K., Sudiasa, K., Golden, N. 2020. Faktor-faktor yang berhubungan dengan terjadinya hipertensi intraabdominal pada pasien dengan peritonitis di RSUP Sanglah Denpasar dari bulan Januari 2017 - Desember 2018. Intisari Sains Medis 11 (2): 814-821. D0I: 10.15562/ism.v11i2.723

\section{ABSTRAK}

Latar belakang dan tujuan: Peritonitis merupakan kondisi kegawatdaruratan di bidang bedah karena dapat menyebabkan terjadinya beberapa komplikasi salah satu yang terberat adalah hipertensi intraabdominal yang dapat berkembang menjadi sindrom kompartemen abdomen. Terdapat beberapa faktor yang menyebabkan hipertensi intraabdominal pada pasien peritonitis. Penelitian ini bertujuan untuk melihat faktor-faktor yang berhubungan dengan terjadinya hipertensi intraabdominal pada pasien peritonitis di RSUP Sanglah bulan Januari 2017-Desember 2018.

Metode: Penelitian analitik crosssectional dilakukan menggunakan teknik total sampling dengan melibatkan 136 responden yang merupakan pasien peritonitis yang dirawat di RSUP Sanglah bulan Januari 2017-Desember 2018. Sumber data berupa rekam medis pasien. Analisis dilakukan untuk melihat faktor yang berhubungan dengan hipertensi intraabdominal pada pasien peritonitis secara bivariat dengan metode chi square dan multivariat dengan regresi logistik.

Hasil: Mayoritas responden berjenis kelamin laki-laki, berusia 15-64 tahun, organ terlibat dalam peritonitis berupa organ padat, peritonitis yang terjadi melalui mekanisme trauma, mengalami sepsis, leukositosis, dan tidak hipoalbumin. Tiga variabel ditemukan signifikan berhubungan yakni peritonitis diakibatkan oleh perforasi organ berongga, kondisi sepsis, dan kondisi hipoalbumin. Hanya kondisi sepsis yang memiliki hubungan murni dengan terjadinya hipertensi intraabdominal. Kondisi sepsis berisiko 0,262 kali lebih besar menyebabkan terjadinya hipertensi intraabdominal pada pasien peritonitis dibandingkan dengan pasien yang tidak mengalami sepsis.

Saran: Sebaiknya dilakukan pemantauan tekanan intraabdominal secara ketat, terutama pada pasien dengan sepsis, hipoalbumin, dan yang dicurigai mengalami perforasi pada organ berongga serta diperlukan penelitian lanjutan dengan jumlah sampel yang lebih besar serta metode penelitian yang lebih superior.
Kata kunci: peritonitis, hipertensi intraabdominal, hipoalbumin, peritonitis, sepsis

Sitasi Artikel ini: Pratama, K.K., Sudiasa, K., Golden, N. 2020. Pratama, K.K., Sudiasa, K., Golden, N. 2020. Faktor-faktor yang berhubungan dengan terjadinya hipertensi intraabdominal pada pasien dengan peritonitis di RSUP Sanglah Denpasar dari bulan Januari 2017 - Desember 2018. Intisari Sains Medis 11 (2): 814-821. D0I: 10.15562/ism.v11i2.723 


\section{PENDAHULUAN}

Kasus peritonitis merupakan masalah yang sering ditemukan dalam dunia kedokteran. Perforasi pada organ berongga saluran cerna meliputi perforasi gaster, dudodenum, ileu-jejunum, appendiks dan kolorektal. Kasus peritonitis dapat terjadi baik melalui trauma maupun non-trauma. ${ }^{1,2}$ Penyebab perforasi dapat berupa trauma tumpul maupun tajam. Penyebab terjadinya peritonitis secara non trauma antara lain penggunaan aspirin maupun obat antiinflamasi non steroid jangka panjang yang menyebabkan perforasi gaster, apendisitis berat yang menyebabkan perforasi appendiks, serta kondisi diverticulosis pada saluran cerna bagian bawah. ${ }^{2,3}$

Peritonitis merupakan suatu kondisi kegawatdaruratan di bidang bedah karena dapat menyebabkan terjadinya beberapa komplikasi salah satunya yang terberat adalah kondisi hipertensi intraabdominal yang data berkembang menjadi sindrom kompartemen abdomen. ${ }^{1,3}$

Terjadinya peningkatan tekanan intraabdominal yang diakibatkan oleh penambahan volume intraabdominal yang tidak disertai dengan penambahan luas dari rongga abdomen itu sendiri. ${ }^{4,5}$ Pada saat tekanan intraabdominal $>12 \mathrm{mmHg}$ maka kondisi ini disebut sebagai hipertensi intraabdominal, sedangkan jika tekanan intraandomen sudan $>20 \mathrm{mmHg}$ maka disebut dengan abdominal kompartmen sindrom. ${ }^{5-7}$ Peningkatan tekanan intraabdominal yang terjadi secara terus menerus dapat mengakibatkan terjadinya kerusakan organ yang bersifat irreversibel. Organ-organ yang mungkin terkena antara lain ginjal, liver, jantung, paru-paru, dan organ gastrointestinal. Pada saat terjadi peningkatan tekana intraabdominal, terjadi gangguan perfusi ke sel, sehingga sel menjadi iskemia, kemudian sel menjadi edema dan kemudian diikuti dengan perubahan permeabilitias. ${ }^{8,9}$ Selanjutnya terjadi edema jaringan karena adanya perpindahan cairan di tingkat intraseluler ke instertitial. Pada saat yang sama juga terjadi gangguan dari endotel pembuluh darah akibat penekanan langsung dari intraabdominal, selanjutnya terjadi pelepasan mediator inflamasi, yang dapat semakin menambah tekanan intra abdomen. ${ }^{9,10}$ Peningkatan tekanan intraabdominal yang terus berjalan akan semakin memperburuk kondisi perfusi organ-organ intraabdominal. Kondisi ini jika terus dibiarkan akan mengakibatkan terjadinya hipertensi intraabdominal yang jika tetap tidak terdeteksi, maka pasien akan jatuh ke dalam kondisi sindrom kompartemen abdominal. Jika kondisi ini tidak mendapatkan penanganan yang adekuat, makan akan dapat mengakibatkan terjadinya kerusakan organ yang bersifat multiple. Kondisi trauma yang disertai dengan kerusakan organ multipel tentu saja akan meningkatkan angka mortalitas dan morbiditas. ${ }^{11,12}$

Berdasarkan literatur didapatkan beberapa kondisi yang berhubungan degan terjadinya hipertensi intraabdominal pada pasien dengan peritonitis, antara lain faktor demografi pasien seperti usia dan jenis kelamin, kondisi klinis pasien berupa indeks massa tubuh, kondisi sepsis, lokasi perforasi, mekanisme terjadinya perforasi. .,13 $^{13}$ Sedangkan dari data laboratorium faktor risiko yang mempengaruhi adanya leukositosis dan kondisi hipoalbumin. Faktor-faktor tersebut perlu untuk diteliti lebih lanjut apakah signifikan berhubungan dengan terjadinya hipertensi intraabdominal pada pasien dengan peritonitis. ${ }^{13,14}$

Rumah Sakit Umum Pusat Sanglah Denpasar merupakan rumah sakit terbesar di Bali dengan angka kunjungan pasien yang tinggi setiap harinya. Adanya kasus peritonitis di RSUP Sanglah Denpasar cukup sering ditemukan dan menyebabkan terjadinya hipertensi intraabdominal yang berujung pada terjadinya sindrom kompartemen abdominal apabila tidak dilakukan penanganan dengan tepat. Cukup sering dijumpainya kasus tersebut mengharuskan para praktisi kesehatan, terutama dokter bedah untuk mengetahui bagaimana penanganan hipertensi intraabdominal agar tidak berkembang menjadi sindrom kompartemen intraabdominal yang berujung pada kematian pasien serta apa saja faktor-faktor berhubungan dengan terjadinya hipertensi intraabdominal tersebut, khususnya pada pasien dengan peritonitis.

Berdasarkan penelitian-penelitian serupa yang sudah pernah dilakukan sebelumnya masih terdapat beberapa pertentangan tentang faktor risiko terjadinya hipertensi intraabdominal. Pada penelitian ini akan dibandingkan hasil yang didapat dengan penelitian-penelitian serupa sebelumnya, sehingga kita dapat mengetahui faktor risiko mana yang berhubungan dengan hipertensi intraabdominal pada peritonitis. Diketahuinya hubungan tersebut diharapkan mampu menjadi acuan klinis untuk mengendalikan faktor risiko hipertensi intraabdominal dan menurunkan angka morbiditas serta mortalitasnya.

\section{METODE}

Rancangan penelitian ini menggunakan studi analitik cross sectional (potong lintang) yang dilakukan di RSUP Sanglah Denpasar, selama periode September 2017 hingga Maret 2019. Studi ini berbasis rekam medis, untuk mengetahui faktor-faktor risiko klinis dari terjadinya hipertensi intraabdominl. Kriteria inklusi dalam penelitian 
ini adalah pasien dengan perforasi orga berongga saluran cerna di RSUP Sanglah. Sedangkan kriteria eksklusi dari penelitian ini yaitu pasien dengan kehamilan, riwayat menjalani laparotomy sebelumnya, tidak dilakukan pengukuran tekanan intraabdominal, dan rekam medis tidak lengkap. Penelusuran faktor risiko yang dilakukan adalah usia, jenis kelamin, keterlibatan organ berongga, mekanisme peritonitis (trauma atau non trauma), kondisi sepsis, status albumin, dan status leukosit.

Analisis data dalam penelitian ini menggunakan bantuan perangkat lunak SPSS versi 25.0 untuk windows, analisis deskriptif digunakan untuk mencari distribusi dari karakteristik sampel, uji chi-square dan analisis risiko digunakan untuk mencari hubungan antara faktor-faktor risiko yang diteliti terhadap hipertensi intraabdominal, kemudian diakhir dilakukan uji multivariate regresi logistik untuk mengetahui faktor risiko yang paling berperan terhadap terjadinya hipertensi intraabdominal. Seluruh nilai dianggap bermakna apabila $\mathrm{p}<0,05$.

Tabel 1. Karakteristik subjek penelitian

\begin{tabular}{|c|c|c|c|}
\hline \multirow[b]{2}{*}{ Variabel } & \multicolumn{2}{|c|}{ Hipertensi Intraabdominal } & \multirow{2}{*}{$\begin{array}{c}n=136 \\
n(\%)\end{array}$} \\
\hline & $\begin{array}{c}\text { Ya } \\
\text { n (\%) }\end{array}$ & $\begin{array}{l}\text { Tidak } \\
\text { n (\%) }\end{array}$ & \\
\hline \multicolumn{4}{|l|}{ Jenis Kelamin } \\
\hline - $\quad$ Laki-laki & $41(30,1)$ & $56(41,2)$ & $97(71,3)$ \\
\hline - $\quad$ Perempuan & $20(14,7)$ & $19(14,0)$ & $39(28,7)$ \\
\hline Usia (rerata $\pm S D$; rentang usia) & \multicolumn{2}{|c|}{$41,56 \pm 21,53(4-95)$} & \\
\hline - Usia 15-64 tahun & $47(34,6)$ & $48(35,3)$ & $95(69,9)$ \\
\hline - Usia $<15$ tahun dan $>64$ tahun & $14(10,3)$ & $27(19,9)$ & $41(30,1)$ \\
\hline \multicolumn{4}{|l|}{$\begin{array}{l}\text { Mekanisme terjadinya perfosi organ } \\
\text { berongga }\end{array}$} \\
\hline - Non-trauma & $29(21,3)$ & $43(31,6)$ & $72(52,9)$ \\
\hline - Trauma & $32(23,5)$ & $32(23,5)$ & $64(47,1)$ \\
\hline $\begin{array}{l}\text { Kondisi sepsis berdasarkan skor } \\
\text { qSOFA }\end{array}$ & \multicolumn{2}{|c|}{$1,96 \pm 0,788(1-3)$} & \\
\hline - $\quad$ Sepsis $($ skor $\geq 2)$ & $54(39,7)$ & $37(27,2)$ & $91(66,9)$ \\
\hline - $\quad$ Tidak sepsis $($ skor $<2)$ & $7(5,1)$ & $38(27,9)$ & $45(33,1)$ \\
\hline $\begin{array}{l}\text { Kadar albumin (rerata } \pm S D \text {; rentang } \\
\text { kadar albumin) }\end{array}$ & \multicolumn{2}{|c|}{$3,26 \pm 0,87(1,0-5,4)$} & \\
\hline $\begin{array}{l}\text { - Hipoalbumin (albumin }<2,5 \mathrm{gr} / \\
\mathrm{dl} \text { ) }\end{array}$ & $17(12,5)$ & $7(5,1)$ & $24(17,6)$ \\
\hline $\begin{array}{l}\text { - Tidak hipoalbumin (albumin } \geq \\
2,5 \mathrm{gr} / \mathrm{dl} \text { ) }\end{array}$ & $44(32,4)$ & $68(50,0)$ & $114(82,4)$ \\
\hline $\begin{array}{l}\text { Kadar leukosit (rerata } \pm \text { SD; rentang } \\
\text { kadar leukosit) x 103/mm3 }\end{array}$ & \multicolumn{2}{|c|}{$17,13 \pm 9,84(1,61-73,82)$} & \\
\hline $\begin{array}{l}\text { Leukositosis (kadar leukosit } \\
\left.>10.000 / \mathrm{mm}^{3}\right)\end{array}$ & $50(36,8)$ & $58(42,6)$ & $108(79,4)$ \\
\hline $\begin{array}{l}\text { Tidak leukositosis (kadar leukosit } \\
\leq 10.000 \mathrm{~mm}^{3} \text { ) }\end{array}$ & $11(8,1)$ & $17(12,5)$ & $28(20,6)$ \\
\hline
\end{tabular}

\section{HASIL PENELITIAN}

Jumlah sampel dalam penelitian ini sebanyak 103 responden, karakteristik subjek dapat dilihat pada Tabel 1. Responden pada penelitian ini memiliki karakteristik mayoritas berusia produktif yakni sebanyak 95 responden (69,9\%) dengan ratarata usia responden 41,56 tahun dan rentang usia 4 hingga 95 tahun. Dari segi jenis kelamin, mayoritas berjenis kelamin laki-laki yakni meliputi 97 responden (69,9\%). Organ sumber terjadinya peritonitis mayoritas berasal dari organ berongga yakni sebanyak 83 responden (61\%) dan terjadi melalui mekanisme non trauma yang ditemukan pada 72 responden $(52,9 \%)$

Kondisi sepsis pada responden dinilai dari skor qSOFA, dimana penilaian meliputi kesadaran, tekanan darah, dan laju respirasi. Pada penelitian ini didapatkan rerata skor qOSFA pada responden penelitian adalah sebesar 1,96 dengan mayoritas responden memiliki skor qSOFA $\geq 2$ atau digolongkan mengalami kondisi sepsis yakni terjadi pada 91 responden $(66,9 \%)$.

Kadar albumin pada responden penelitian ini didapatkan rerata sebesar 3,26 gram/dl dengan rentang kadar albumin antara 1,0-5,4 gram/dl. Mayoritas responden tidak mengalami hipoalbumin yakni sebanyak 114 responden $(82,4 \%)$ sedangkan kondisi hipoalbumin hanya didapatkan pada 24 responden (17,6\%). Untuk kadar leukosit didapatkan rerata sebesar $17,13 \times 10^{3}$ $\mathrm{mm}^{3}$ dengan rentang nilai kadar leukosit berkisar $1,61-73,82 \times 10^{3} / \mathrm{mm}^{3}$. Mayoritas responden tergolong mengalami leukositosis yang didapatkan pada $108(79,4 \%)$ responden.

Berdasarkan hasil analisis univariat didapatkan pasien dengan perforasi organ berongga yang mengalami hipertensi intraabdominal tidak terlalu jauh berbeda jumlahnya dengan pasien peritonitis yang tidak megalami hipertensi intraabdominal, yakni terdapat 61 responden $(44,9 \%)$ dengan hipertensi intraabdominal dan sebanyak 75 responden (55,1\%) tanpahipertensi intraabdominal. Rerata nilai tekanan intraabdominal pasien adalah 11,69 $\mathrm{mmHg}$ dengan rentang 7,9-15,7 $\mathrm{mmHg}$ (Tabel 2).

Analisis bivariat pada penelitian ini menggunakan metode chisquare untuk menentukan nilai p dari masing-masing variabel. Metode chi square dipilih karena variabel bebas dan tergantung masing-masing terdiri dari dua kelompok dengan jenis variabel nominal. Berdasarkan jenis kelamin, responden dengan jenis kelamin laki-laki yang mengalami hipertensi intraabdominal adalah sebanyak 41 responden $(30,1 \%)$ sedangkan responden berjenis kelamin perempuan yang mengalami hipertensi intraabdominal adalah 
Tabel 2. Perbandingan kejadian hipertensi intraabdominal dan tanpa hipertensi intraabdominal pada pasien dengan peritonitis yang dirawat di RSUP Sanglah pada bulan Januari 2017 hingga Desember 2018

$\begin{array}{cc}\begin{array}{c}\text { Pasien dengan peritonitis yang } \\ \text { dirawat di RSUP Sanglah bulan }\end{array} & \begin{array}{c}\text { Kejadian hipertensi } \\ \text { intraabdominal }\end{array} \\ \begin{array}{c}\text { Januari 2017-Desember } 2018 \\ n=136\end{array} & \mathbf{n}(\%)\end{array}$

Rerata tekanan intraabdominal

\pm SD (rentang) $\quad 61(44,9) \quad 75(55,1)$

$11,69 \pm 1,57(7,9-15,7)$

Tabel 3. Hasil analisis bivariat

\begin{tabular}{|c|c|c|c|c|}
\hline \multirow{2}{*}{ Variabel } & \multicolumn{2}{|c|}{$\begin{array}{c}\text { Hipertensi } \\
\text { Intraabdominal }\end{array}$} & \multirow{2}{*}{$\begin{array}{c}\text { PR } \\
\text { IK 95\% }\end{array}$} & \multirow{2}{*}{ Nilai $p$} \\
\hline & $\begin{array}{c}\text { Ya } \\
\text { n (\%) }\end{array}$ & $\begin{array}{l}\text { Tidak } \\
\text { n (\%) }\end{array}$ & & \\
\hline $\begin{array}{l}\text { Jenis kelamin } \\
\text { - } \quad \text { Laki-laki } \\
\text { - } \quad \text { Perempuan }\end{array}$ & $\begin{array}{l}41(30,1) \\
20(14,7)\end{array}$ & $\begin{array}{l}56(41,2) \\
19(14,0)\end{array}$ & $\begin{array}{c}0,696 \\
(0,330-1,467)\end{array}$ & 0,339 \\
\hline $\begin{array}{l}\text { Usia } \\
\begin{array}{l}\text { - } \\
\text { - }\end{array} \quad<15 \text { tahun dan }>64 \\
\text { tahun }\end{array}$ & $\begin{array}{l}47(34,6) \\
14(10,3)\end{array}$ & $\begin{array}{l}48(35,3) \\
27(19,9)\end{array}$ & $\begin{array}{c}1,88 \\
(0,883-4,040)\end{array}$ & 0,099 \\
\hline $\begin{array}{l}\text { Organ yang terlibat dalam } \\
\text { peritonitis } \\
\text { - Organ berongga } \\
\text { - Organ padat }\end{array}$ & $\begin{array}{l}30(22,1) \\
31(22,8)\end{array}$ & $\begin{array}{l}50(39,0) \\
22(16,2)\end{array}$ & $\begin{array}{c}0,402 \\
(0,198-0,814)\end{array}$ & $0,011^{\star}$ \\
\hline $\begin{array}{l}\text { Mekanisme terjadinya } \\
\text { peritonitis } \\
\text { - Non-trauma } \\
\text { - Trauma }\end{array}$ & $\begin{array}{l}29(21,3) \\
32(23,5)\end{array}$ & $\begin{array}{l}43(31,6) \\
32(23,5)\end{array}$ & $\begin{array}{c}0,674 \\
(0,342-1,331)\end{array}$ & 0,255 \\
\hline $\begin{array}{l}\text { Sepsis } \\
\text { - } \quad \text { Sepsis } \\
\text { - } \quad \text { Tidak sepsis }\end{array}$ & $\begin{array}{c}54(39,7) \\
7(5,1)\end{array}$ & $\begin{array}{l}37(27,2) \\
38(27,9)\end{array}$ & $\begin{array}{l}7,923 \\
(3,195- \\
19,647)\end{array}$ & $0,000^{*}$ \\
\hline $\begin{array}{l}\text { Kadar albumin } \\
\text { - } \quad \text { Hipoalbumin } \\
\text { - } \quad \text { Tidak hipoalbumin }\end{array}$ & $\begin{array}{l}17(12,5) \\
44(32,4)\end{array}$ & $\begin{array}{c}7(5,1) \\
68(50,0)\end{array}$ & $\begin{array}{c}3,753 \\
(1,439-9,787)\end{array}$ & $0,005^{\star}$ \\
\hline $\begin{array}{l}\text { Leukositosis } \\
\text { - } \quad \text { Leukositosis } \\
\text { - } \quad \text { Tidak leukositosis }\end{array}$ & $\begin{array}{c}50(36,8) \\
11(8,1)\end{array}$ & $\begin{array}{l}58(42,6) \\
17(12,5)\end{array}$ & $\begin{array}{c}1,332 \\
(0,571-3,109)\end{array}$ & 0,506 \\
\hline
\end{tabular}

sebanyak 20 responden (12,7\%) (Tabel 3).

Berdasarkan usia, pasien yang mengalami hipertensi intraabdominal mayoritas tergolong ke dalam usia 15-64 tahun yakni sebanyak 47 responden $(34,6 \%)$. Terjadinya hipertensi intraabdominal berdasarkan organ sumber terjadinya peritonitis ditemukan hampir sama baik pada organ padat maupun berongga (22,8\% dan 22,1\%) (Tabel 3).

Berdasarkan kondisi sepsis, hipertensi intraabdominal lebih banyak ditemukan pada responden dengan kondisi sepsis yakni sebanyak $54(39,7 \%)$ dan pada pasien tanpa sepsis, kejadian hipertensi intraabdominal ditemukan hanya pada 7 responden (5,1\%). Responden dengan kondisi hipoalbumin yang mengalami hipertensi intraabdominal ditemukan sebanyak 17 responden $(12,5 \%)$ jumlah ini lebih sedikit bila dibandingkan dengan responden tanpa hipoalbumin yang mengalami hipertensi intraabdominal yakni sebanyak 44 responden (32,4\%). Berdasarkan kondisi leukositosis, responden dengan leukositosis lebih banyak yang mengalami hipertensi intraabdominal yakni sebanyak 50 responden $(36,8 \%)$ bila dibandingkan dengan pasien tanpa leukositosis yang mengalami hipertensi intraabdominal yakni sebanyak 11 responden (8,1\%) (Tabel 3).

Pada variabel organ sumber terjadinya peritonitis didapatkan nilai $\mathrm{p}$ sebesar 0,011 yang kurang dari 0,05 dan nilai PR sebesar 0,402 (IK 95\% 0,198-0,814) yang berarti variable tersebut signifikan secara statistik dimana sumber organ peritonitis berupa organ berongga memiliki kuat hubungan dengan terjadinya hipertensi intraabdominal sebanyak 0,402 kali. Untuk variabel selanjutnya yakni adanya sepsis memiliki nilai p $0,000<0,05$ dan nilai PR 7,923 (IK 95\% 3,195-19,647) menyatakan bahwa variabel sepsis signifikan secara statistic dimana kondisi sepsis memiliki kuat hubungan dengan terjadinya hipertensi intraabdominal 7,923 kali lebih besar dibandingkan responden yang tdiak sepsis. Variabel ketiga yang juga signifikan sacara statistik adalah adanya kondisi hipoalbumin dimana variabel tersebut memiliki nilai $\mathrm{p} 0,005$ $<0,05$ dan nilai PR 3,753 (IK 95\% 1,439-9,787) dimana kondisi hipoalbumin memiliki hubungan 3,753 kali lebih besar untuk terjaidnya hipertensi intraabdominal dibandingkan dengan responden tanpa kondisi hipoalbumin (Tabel 3).

Dari ketujuh variabel dalam penelitian ini didapatkan nilai $\mathrm{p}$ yang beragam, dimana variabel dengan nilai $\mathrm{p} \leq 0,05$ akan diikutkan ke dalam analisis selanjutnya yakni analisis multivariat. Berdasarkan analisis bivariat seperti yang tertera pada Tabel 5.3 terdapat tiga buah variabel yang signifikan yakni organ sumber peritonitis, kondisi sepsis, dan kondisi hipoalbumin. Sedangkan variabel yang tidak memenuhi syarat yakni usia, jenis kelamin, mekanisme terjadinya peritonitis, dan kondisi leukositosis karena memiliki nilai $\mathrm{p}$ lebih besar dari 0,05 (Tabel 3).

Variabel yang diikutsertakan dalam analisis multivariat pada penelitian ini adalah variabelvariabel bebas dengan nilai $p \leq 0,05$ pada analisis bivariat. Alasan memilih nilai kemaknaan ini adalah untuk menghindari kemungkinan terdapatnya variabel yang tidak bermakna secara statistik tetapi bermakna secara biologis sehingga harus dimasukkan ke dalam analisis bivariat. 
Tabel 4. Hasil Analisis Multivariat

\begin{tabular}{lllccc}
\hline & Variabel & Nilai p & $\begin{array}{c}\text { Prevalence } \\
\text { Ratio }\end{array}$ & $\begin{array}{c}\text { Patas } \\
\text { Bawah }\end{array}$ & $\begin{array}{c}\text { Batas } \\
\text { Atas }\end{array}$ \\
\hline \multirow{2}{*}{ Langkah 1 } & Keterlibatan organ & 0,193 & 1,404 & 0,842 & 2,340 \\
& Kondisi sepsis & 0,003 & 0,302 & 0,135 & 0,674 \\
& $\begin{array}{l}\text { Kondisi } \\
\text { hipoalbumin }\end{array}$ & 0,115 & 0,633 & 0,359 & 1,117 \\
\hline \multirow{2}{*}{ Langkah 2 } & Kondisi sepsis & 0,002 & 0,279 & 0,126 & 0,616 \\
& Kondisi & 0,153 & 0,633 & 0,377 & 1,165 \\
\hline Langkah 3 & Kondisi sepsis & 0,001 & 0,262 & 0,119 & 0,576 \\
\hline
\end{tabular}

Variabel bebas dengan nilai $\mathrm{p} \leq 0,05$ yang akan diikutsertakan dalam analisis regresi logistik adalah keterlibatan organ penyebab peritonitis, kondisi sepsis, dan kondisi hipoalbumin. Dimana secara rinci hasil analisis regresi logistik disajikan pada Tabel 4.

Hasil analisis menunjukkan terdapat satu variabel yang paling signifikan diantara tiga variabel yang masuk ke dalam analisis multivariat, yakni variabel kondisi sepsis. Variabel kondisi sepsis memiliki nilai $\mathrm{p} \leq 0,001$ dan PR sebesar 0,262 (0,1190,576 IK 95\%), dimana dapat disimpulkan bahwa variabel kondisi sepsis memiliki hubungan dengan terjadinya hipertensi intraabdominal pada pasien dengan peritonitis yang dirawat di RSUP Sanglah Denpasar dan nilai PR 0,262 menyatakan bahwa pasien peritonitis dengan kondisi sepsis berisiko untuk mengalami hipertensi intraabdominal sebanyak 0,262 kali lebih besar dibandingkan pasien peritonitis yang tidak mengalami sepsis. Sedangkan kedua variabel lainnya yakni keterlibatan organ sebagai sumber peritonitis dan kondisi hipoalbumin tidak berhubungan dengan terjadinya hipertensi intraabdominal karena memiliki nilai $p>0,05$ dan memiliki nilai 1 pada interval prevalence rationya (PR) (Tabel 4).

Pada Tabel 4 langkah 1 didapatkan data hanya kondisi sepsis yang yang mempunyai pengaruh murni terhadap kejadian hipertensi intraabdominal pada pasien peritonitis dengan $\mathrm{p}$-value $<0,05$ sedangkan sumber organ peritonitis dan kondisi hipoalbumin tidak mempunyai pengaruh murni terhadap terjadinya hipertensi intraabdominal pada pasien dengan peritonitis. Hal ini dapat dilihat pada step 2 dan step 3 setelah diujikan bersamasama tetap hanya kondisi sepsis yang signifikan dengan p-value 0,001 , hal ini berarti hanya kondisi sepsis yang mempunyai hubungan murni terhadap terjaidnya hipertensi intraabdominal pada pasien dengan peritonitis dengan nilai $\operatorname{Exp}(\mathrm{B})>1$ yang berarti faktor kondisi sepsis menjadi faktor risiko yang meningkatkan terjadinya hipertensi intraabdominal pada pasien peritonitis.

\section{PEMBAHASAN}

Penelitian ini melibatkan pasien dengan peritonitis yang mengalami hipertensi intraabdominal. Perbandingan jumlah pasien peritonitis yang mengalami hipertensi intraabdominal ditemukan tidak jauh berbeda. Pasien peritonitis yang mengalami hipertensi intraabdominal diketemukan mayoritas berjenis kelamin laki-laki, penelitian oleh Balogh sendiri pada tahun 2003 menyatakan bahwa dari 180 sampel sebanyak $70 \%$ yang mengalam hipertensi intraabdominal adalah lakilaki. ${ }^{15}$ Penelitian lainnya yang juga menyediakan data demografi adalah penelitian oleh Iyer dkk. pada tahun 2014 yang melakukan studi prospektif terhadap pasien di ruang rawat intensif dengan hipertensi intraabdominal ditemukan dari total 156 pasien dengan hipertensi intraabdominal sebanyak 108 sampel berjenis kelamin laki-laki. ${ }^{16}$ Prevalensi pada laki-laki yang lebih tinggi dibandingkan pada perempuan kemungkinan berkaitan dengan aktivitas fisik laki-laki yang lebih aktif sehingga lebih rentan mengalami risiko untuk cedera dan mengalami kecelakaan. ${ }^{13}$

Mayoritas pasien peritonitis dengan hipertensi intraabdominal pada penelitian berusia antara 1564 tahun, penelitian lain yang juga menemukan hal serupa adalah penelitian oleh Balogh dkk. pada tahun 2003 terhadap pasien dengan trauma tumpul abdomen menyebutkan dari 162 sampel, rata-rata usia pasien yang mengalami hipertensi intraabdominal adalah 41 tahun. ${ }^{15}$ Dimana rerata usia pasien pada penelitian ini juga memiliki kisaran angka yang sama yakni adalah 41,56 tahun. Mayoritas penelitian menunjukkan bahwa kejadian hipertensi intraabdominal terjadi pada kelompok usia produktif, hal tersebut dapat diakibatkan bahwa pada kelompok usia produktif cenderung lebih aktif, memiliki banyak kegiatan di luar rumah, serta mereka yang termasuk dalam kelompok pekerja sehingga risiko untuk mengalami kecelakaan maupun kondisi yang berkaitan dengan terjadinya hipertensi intraabdominal lebih besar. ${ }^{13}$

Pada penelitian ini kedua variabel demografi di atas ditemukan tidak berhubungan dengan terjadinya hipertensi intraabdominal pada pasien peritonitis. Variabel lain yang juga diketahui tidak memiliki hubungan yang signifikan adalah mekanisme terjadinya peritonitis dan kondisi leukositosis.

Mayoritas pasien dengan peritonitis yang mengalami hipertensi intraabdominal pada penelitian ini mengalami peritonitis melalui mekanisme trauma. Mekanisme trauma yang 
terjadi pada pasien tersebut antara lain ruptur ginjal, hepar, lien, perforasi kolon dan gaster. Hasil ini berbeda dengan Studi oleh Pandian dkk. pada tahun 2016 yang melibatkan 80 sampel dengan peritonitis menunjukkan bahwa penyebab atau mekanisme tersering terjadinya peritonitis adalah akibat ulkus gaster dan duodenum sebanyak 39 kasus, sedangkan untuk kasus trauma sebanyak 19 kasus, akibat infeksi bakteri pada jejunoileum dan appendiks sebanyak 21 kasus, dan hanya satu kasus akibat keganasan. ${ }^{17}$

Pada penelitian ini sebagian besar pasien peritonitis dengan hipertensi intraabdominal mengalami leukositosis. Temuan ini sejalan dengan penelitian oleh Ke dkk. pada tahun 2011 terhadap 58 pasien dengan akut pankreatitis keseluruhan memiliki rerata nilai leukosit sebesar $14,2 \times 10^{3} /$ $\mathrm{mm}^{3}$ dengan rentang nilai leukosit 10,5-19 $\times 10^{3} /$ $\mathrm{mm}^{3}$. Dari 58 pasien dengan leukositosis tersebut sebanyak 62\% (36 pasien) mengalami hipertensi intraabdominal. Penelitian lainnya yang juga sejalan dengan hasil penelitian ini adalah penelitian oleh Su dkk. pada tahun 2015 pada 433 pasien dengan peritonitis sebanyak 161 pasien mengalami leukositosis. Penelitian lainnya oleh Iyer dkk. pada tahun 2014 menunjukkan dari 403 pasien yang dirawat di unit rawat intensif sebanyak 9 pasien mengalami peritonitis dan keseluruhan pasien dengan peritonitis tersebut mengalami hipertensi intraabdominal. ${ }^{16,18}$

Pada penelitian ini variabel yang ditemukan memiliki hubungan signifikan dengan terjadinya hipertensi intraabdominal adalah sumber organ penyebab peritonitis, kondisi sepsis dan kondisi hipoalbumin.

Pada penelitian ini dilakukan evaluasi terhadap faktor yang berhubungan dengan terjadinya hipertensi intraabdomen pada pasien dengan peritonitis. Dari analisa yang dilakukan didapatkan 3 faktor utama yang berhubungan dengan hipertensi intraabdomen pada peritonitis, yaitu sepsis, albumin, dan keterlibatan organ. Pada analisa multivariat didapatkan sepsis memiliki hubungan yang paling murni dibandingkan dengan 2 variabel lainnya yang juga signifikan, yaitu hipoalbumin dan keterlibatan organ.

Hal ini sesuai dengan penelitian yang dilakukan oleh Ke dkk. di mana didapatkan hubungan sepsis dengan hipertensi intraabdomen, dengan nilai $\mathrm{p}=0,001$. Angka ini menunjukkan bahwa hasil penelitian ini bermakna secara statistik. Apabila dikaitkan dengan teori, sepsis dapat menyebabkan peningkatan tekanan intraabdomen dikarenakan pada kondisi sepsis terjadi pelepasan mediator proinflamasi yang mengakibatkan meningkatkanya permeabilitas vaskuler. ${ }^{19}$ Kondisi ini mengakibatkan pergeseran cairan dari ruang intravaskuler ke dalam insterstitial hingga ke dalam lumen usus. Akumulasi cairan di dalam ruang interstitial mengakibatkan edema pada organ yang terlibat. Jika hal ini terjadi pada organ intraabdomen, maka akan meningkatkan volume intraabdomen yang kemudian meningkatkan tekanan di dalam rongga intraabdomen yang jika dibiarkan berlanjut akan menjadi hipertensi intraabdomen atau bahkan sindrome kompartement abdomen. Kondisi edema pada organ intraabdomen diperberat dengan perpindahan cairan ke dalam ruang intralumen usus yang sudah kehilangan kemampuan pasasenya. Hal ini mengakibatkan penambahan volume yang disertai dengan pertumbuhan bakteri intralumen. Hal ini tentu akan semakin menambah tekanan intraabdomen.

Pada penelitian ini ditemukan adanya hubungan signifikan antara sumber terjadinya peritonitis pada organ berongga dengan hipertensi intraabdominal. Hasil ini sesuai dengan penelitan yang dilakukan oleh Jain pada 100 pasien dengan trauma abdomen, lokasi perforasi pada lambung ditemukan sebanyak 6 pasien, di duodenum sebanyak 3 pasien, di jejunoileum sebanyak 80 pasien, dan 11 pasien mengalami peforasi di kolorektal. ${ }^{20}$ Studi oleh Pandian dkk. pada tahun 2016 yang melibatkan 80 sampel dengan peritonitis menunjukkan hasil bahwa lokasi perforasi terbanyak adalah pada duodenum (36 sampel), disusul oleh lambung (16 kasus), appendiks (16 kasus), jejunoileum (11 kasus), dan kolon (1 kasus). ${ }^{17}$

Pada penelitian ini variabel hipoalbumin memiliki hubungan yang signifikan dengan terjadinya hipertensi intraabdominal. Penelitian lain yang juga menemukan hal serupa adalah penelitian oleh Iyer dkk. pada tahun 2014 dimana menemukan bahwa mayoritas pasien dengan hipertensi intraabdominal memiliki nilai albumin yang lebih rendah dibandingkan dengan pasien hipertensi intraabdominal dengan nilai $\mathrm{p}=0,002 \cdot{ }^{16}$ Apabila dikaitkan dengan teori, kondisi hipoalbumin dapat menyebabkan peningkatan tekanan intrabdominal akibat adanya peritonitis yang disebabkan oleh peritonitis. Pada peritonitis perforasi terjadi suatu kebocoran organ, dimana akan terjadi translokasi cairan tubuh dan juga bakteri ke rongga intraabdomen yang akan menimbulkan reaksi inflamasi serta infeksi. Pada kondisi tersebut dapat terjadi hipoalbuminemia dimana serum albumin keluar dari kapiler akibat peningkatan permeabilitas kapier yang disebabkan oleh reaksi inflamasi. Bocornya albumin ke ruang interstitial dimana pada kasus peritonitis yakni ruang intrabdomen akan menambah volume intraabdomen yang berpengaruh terhadap 
peningkatan tekanan intraabdominal. ${ }^{21}$

Pada beberapa penelitian yang mencari hubungan antara kondisi hipoalbumin dan sepsis disebutkan bahwa terdapat hubungan antara sepsis dengan hipoalbumin. Pada sepsis dan kondisi peningkatan tekanan intraabdomen, terjadi iskemia jaringan, hal ini mengakibatkan terjadinya metabolisme katabolik dimana terjadi pemecahan protein untuk proses metabolisme. Proses ini mengakibatkan terjadinya penurunan kadar albumin yang didahului oleh kondisi sepsis. Hal ini sesuai dengan data yang didapatkan oleh peneliti, di mana pada pasien yang sepsis ditemukan kadar albumin yang mendekati batas hipoalbumin. Namun alasan yang dapat menjelaskan mengapa variabel hipoalbumin ditemukan tidak signifikan berhubungan dengan terjadinya hipertensi intraabdominal pada penelitian ini adalah bahwa pada penelitian ini dari 136 sampel hanya ditemukan sebanyak 24 sampel $(17,6 \%)$ yang mengalami hipoalbumin dan $17 \quad(12,5 \%)$ diantaranya mengalami hipertensi intraabdominal. Jumlah sampel peritonitis yang mengalami hipoalbumin tersebut jauh lebih sedikit dibandingkan pasien peritonitis yang tidak mengalami hipoalbumin, sehingga menurut peneliti jumlah tersebut kurang sesuai dengan teori yang menyatakan, bahwa pada pasien sepsis pasti akan diikuti oleh terjadinya hipoalbumin karena metabolism sel yang meningkat dan meningkatkan penggunaan protein oleh sel. ${ }^{3,15}$ Argumentasi lainnya adalah pada penelitian ini didapatkan nilai rerata albumin adalah sebesar 3,26 mg/dl dengan kadar albumin terendah $1,0 \mathrm{mg} / \mathrm{dl}$. Nilai rerata albumin yang didapatkan pun belum dapat dikategorikan sebagai kondisi hipoalbumin, meskipun pada sampel kita lihat sebanyak 91 sampel $(66,9 \%)$ mengalami sepsis tetapi tidak diikuti dengan meningkatnya jumlah sampel dengan hipoalbumin. Hal ini dapat terjadi diakibatkan oleh beberapa hal yakni kondisi hipoalbumin yang terjadi pada pasien peritonitis yang menjadi sampel penelitian ini masih dalam proses saat dilakukan pengecekan kadar albumin seiring dengan proses sepsis yang terjadi, sehingga belum terjadi penurunan kadar albumin. ${ }^{5,17}$

Titik akhir pada penelitian ini adalah korelasi klinis yang dapat diaplikasikan pada kondisi di unit gawat darurat maupun unit perawatan intensif dimana pasien peritonitis dirawat. Yang pertama, perlu dilakukan monitoring tekanan intraabdominal secara ketat seta manajemen aktif untuk seluruh pasien sepsis, baik kasus bedah maupun non bedah untuk mengetahui terjadinya peningkatan tekanan intraabdomen yang mengarah ke hipertensi intraabdominal lebih awal. Kelemahan pada penelitian ini adalah masih diperlukannya jumlah sampel yang lebih besar serta digunakannya metode penelitian lain yang lebih superior untuk menentukan prediktor terjadinya hipertensi intraabdominal. Selain itu pada studi ini juga belum diteliti variabel lain yang diyakini berhubungan dengan terjadinya peningkatan tekanan intraabdominal seperti indeks massa tubuh.

Hasil akhir dari penelitian ini diharapkan dapat memberikan data dasar untuk penelitian selanjutnya untuk meneliti faktor risiko sepsis sebagai prediktor terjadinya hipertensi intraabdominal.

\section{SIMPULAN}

Karakteristik pasien dengan peritonitis yang mengalami hipertensi intraabdominal yang dirawat di RSUP Sanglah Denpasar pada bulan Januari 2017 hingga Desember 2018 mayoritas berjenis kelamin laki-laki, berusia 15-64 tahun, organ yang terlibat dalam peritonitis berupa organ padat, pasien dengan peritonitis yang terjadi melalui mekanisme trauma, mengalami sepsis, leukositosis, dan tidak hipoalbumin. Terdapat tiga variabel yang ditemukan signifikan berhubungan dengan terjadinya hipertensi intraabdominal pada pasien peritonitis yakni peritonitis yang diakibatkan oleh perforasi organ berongga, kondisi sepsis, dan kondisi hipoalbumin. Namun hanya kondisi sepsis yang memiliki hubungan murni dengan terjadinya hipertensi intraabdominal, dimana kondisi sepsis berisiko 0,262 kali lebih besar untuk menyebabkan terjadinya hipertensi intraabdominal pada pasien peritonitis dibandingkan dengan pasien yang tidak mengalami sepsis.

\section{KONFLIK KEPENTINGAN}

Penulis menyataan tidak terdapat konflik kepentingan terkait publikasi dari artikel ini.

\section{ETIKA DALAM PENELITIAN}

Penelitian ini telah di setujui oleh Komite Etik Fakultas Kedokteran Universitas Udayan/RSUP Sanglah Denpasar dengan nomer referensi laik etik 620/UN14.2.2.VII./LP/2019.

\section{PENDANAAN}

Penelitian ini tidak mendapatkan pendanaan dari pemerintah maupun sector swasta lainnya.

\section{DAFTAR PUSTAKA}

1. Phadnis J, Pilling JE, Evans TW, Goldstraw P. Abdominal compartment syndrome: a rare complication of plication of the diaphragm. The Annals Of Thoracic Surgery. 
2006;82:334-336.

2. Watts DD, Fakhry SM. Incidence of hollow viscus injury in blunt trauma: an analysis from 275,557 trauma admissions from the East multi-institutional trial. Journal of Trauma and Acute Care Surgery. 2003;54(2):289-294.

3. Espinoza R, and Rodríguez A. Traumatic and nontraumatic perforation of hollow viscera. Surgical Clinics of North America. 2017;77(6):1291-1304.

4. De Waele JJ, De Laet I, Kirkpatrick AW, Hoste E. Intraabdominal hypertension and abdominal compartment syndrome. American Journal of Kidney Diseases. 2011;57(1):159-169.

5. Walker J, Criddle LM. Pathophysiology and management of abdominal compartment syndrome. American Journal of Critical Care. 2003;12:367-371.

6. De Waele JJ, De Laet I, Kirkpatrick AW, and Hoste E. Intraabdominal hypertension and abdominal compartment syndrome. American Journal of Kidney Diseases. 2011;57(1):159-169.

7. Damanik B, Fikri E, Nasution I. Relation between Fiber Diet and Appendicitis Incidence in Children at $\mathrm{H}$. Adam Malik Central Hospital, Medan, North Sumatra-Indonesia. Bali Medical Journal. 2016;5(2):268-271. DOI:10.15562/bmj. v5i2.225

8. Lee RK. Intra-abdominal hypertension and abdominal compartment syndrome a comprehensive overview. Critical Care Nurse. 2012;32:19-31.

9. Roberts DJ, Ball CG, Kirkpatrick AW. Increased pressure within the abdominal compartment: intra-abdominal hypertension and the abdominal compartment syndrome. Curr Opin Crit Care. 2016;22:174-85.

10. Patel DM, Connor Jr M. Intra-abdominal hypertension and abdominal compartment syndrome: an underappreciated cause of acute kidney injury. Advances in chronic kidney disease. 2016;23:160-166.

11. Ivatury RR, Diebel L, Porter JM, Simon RJ. Intra-abdominal hypertension and the abdominal compartment syndrome. Surgical Clinics of North America. 2011;77(4):783-800.
12. Bailey J, Shapiro MJ. Abdominal compartment syndrome. Critical Care. 2000;4(2):22-84

13. Velappan DP, and Kaveri S. Clinical study and management of hollow viscus perforation of abdomen. International Surgery Journal. 2017;4(5):1773-1776.

14. Malbrain ML, Cheatham ML, Kirkpatrick A, Sugrue M. Results from the international conference of experts on intra-abdominal hypertension and abdominal compartment syndrome. I. Definitions. Intensive care medicine. 2017;32(11):1722-1732.

15. Balogh Z, Mckinley BA, Cocanour CS, Kozar RA, Valdivia A, Sailors RM, Moore FA. Supranormal trauma resuscitation causes more cases of abdominal compartment syndrome. Archives of Surgery. 2003;138:637-643.

16. Iyer D, Rastogi P, Åneman A. Early screening to identify patients at risk of developing intra-abdominal hypertension and abdominal compartment syndrome. Acta Anaesthesiologica Scandinavica. 2014;58(10):12671275.

17. Pandian P, Pachaipondy M, Ramula M, and Arulselvan A. Comprehensive study of hollow viscous perforation and its management. IOSR-JDMS. 2016;15(12):1-4.

18. Su YC, Lee $\mathrm{CH}$, Chang WH, and Huang MY. HollowOrgan Perforation in the Emergency Department: Is Time to Diagnosis Prolonged in the Elderly?. International Journal of Gerontology. 2015;9(4):223-227.

19. Ke L, Ni HB, Sun JK, Tong ZH, Li WQ, Li N. Risk factors and outcome of intra-abdominal hypertension in patients with severe acute pancreatitis. World Journal Of Surgery. 2012;36(1):171-178.

20. Jain S, Maske D, Songra MC. Clinical study of hollow viscus injury in abdominal trauma. International Surgery Journal. 2017;5(1):39-44

21. Soeters PB, Wolfe RR, Shenkin A. Hypoalbuminemia: Pathogenesis and Clinical Significance. Journal of Parenteral and Enteral Nutrition. 2018;14(2):145-152.

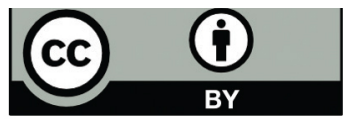

This work is licensed under a Creative Commons Attribution 